\title{
Remembering Guido Martinotti as an Applied Sociologist to the Urban Mobilities and Local Community
}

\author{
Nicolò Costa \\ State University of Rome Tor Vergata, Rome, Italy \\ Email: nicocosta@tiscali.it \\ Received 1 January 2015; accepted 16 January 2015; published 21 January 2015 \\ Copyright (C) 2015 by author and Scientific Research Publishing Inc. \\ This work is licensed under the Creative Commons Attribution International License (CC BY). \\ http://creativecommons.org/licenses/by/4.0/

(c) (i) Open Access

\begin{abstract}
Guido Martinotti (M) has been one of the most relevant representatives of the applied sociology in Italy. The paper explains the origins ad developments of his ideas and researches on the links between urban transformations, tourism/hospitality and human mobilities and the application to the reform of the Italian academic system with the introduction of new courses on tourism (19992001). $M$ and John Urry (U) are the pioneers in the new intersectorial and interdisciplinary approach to the study of tourism included in the broader context of advanced-economy cities, of the cities of information flows, intense exchanges and accelerated mobilities. $M$ stressed a new direction in planning the local community and "hospitable city" between urban marketing and bottomup regulation. In 1999 he pushed for the bill dealing with the nascent specialist degree in "Planning and Management of Tourism Systems" to be discussed in the Italian parliament, which in 2001 passed Law 135 establishing "local tourist systems". M constructed the degree "Tourist Sciences and Local Community" (University of Milano Bicocca) with an educational mix of territorial, social, economic, business, literary and technological disciplines.
\end{abstract}

\section{Keywords}

Martinotti, City Users, New Mobilities, Tourism, Local Community, University Education in Italy

\section{Introduction}

Guido Martinotti (M) died on 5th December 2013 in Paris, while he was taking a taxi from his home in Paris to Charles De Gaulle airport. He was coming back to Milan, the Italian city where he lived as a professor of Urban Sociology (State University of Milan and later State University of Milano Bicocca). From 1996 to 1999 , M col- 
laborated with Luigi Berlinguer, Ministry of University and Scientific Research, to reform the Italian academic system. He had a remarkable role in the new degree of "Tourist Science" (3 years) and "Planning and Management of Tourist Systems" ("magistralis" of 2 years). M's commitment was to stress the role of the sociologist as the facilitator of sustainable development to realise what he defined "the good society".

The objective of the study is to reconstruct: the evolution of the thinking of $\mathrm{M}$, the origins and developments of his ideas and researches on the links between urban transformations, tourism/hospitality and human mobilities; the application of the results of his research and ideas to university education through the establishment of degree courses in tourism.

M was an "applied sociologist" and he wished to see applications of his research results in the attempt to influence political and educational decision-makers.

The method consists in, with regard to scientific research, a synchronic interpretation of M's writings and their diachronic or historical-biographical contextualization, citing also publications I had the honour of writing with him or that he encouraged me to write; with regard to teaching, an analysis of video lectures $\mathrm{M}$ gave for the Consorzio Interuniversitario Uninettuno (distance learning course in Sociology of Tourism and Land Use) and the syllabi of his lectures in the degree course in Tourism and Local Community Sciences in the University of Milan Bicocca.

Therefore, the contents will be divided into two groups:

1) scientific sources dealing directly or indirectly with topics of urban transformations, city users and tourism;

2) sources explicitly related to tourism education at the university level and related teaching issues.

In conclusion, I will underline the appropriateness of orienting studies on tourism toward the post-Fordist production system centred on hospitality/mobility.

\section{Definition of the Main Topics of M's Scientific Research Related to Tourism}

\subsection{Theory of City Users and Mobilities and the Sociological "Discovery" of Tourists}

M's interest in tourism began between 1989 and 1992 when he was writing (reworking incessantly) the third chapter of his book "Metropoli" (Martinotti, 1993), entitled "The four metropolitan populations". M used an original method to outline the new social morphology of the city with an advanced economy. He found the analysis of urban ecology and the Marxist theory of conflict limited because they focused exclusively on the inhabitants, on those permanently resident in the city, whereas it was necessary to focus the research on human mobilities.

$\mathrm{M}$ argued that cities are dynamic organisms and increasingly characterized by information flows and spatial mobilities. This makes the city limits porous and renders the models of governance inherited from the past and the tools of economic, social, demographic and urban diagnosis outdated. To understand how the city is changing, it is necessary to know how and why the residents and the "transient populations" move within the city and between cities, experiencing them and connecting them in a continuously different way over time.

Starting in 1989, M distributed drafts of the third chapter of "Metropoli" to friends who could help clarify specific topics or examine them in more depth. The city populations also included tourists, to which $\mathrm{M}$ had given only indirect attention up to then. Until 1989, he shared the dominant idea in Italian sociology, influenced by French sociology, that tourism was a sector of "free time", which was supposed to be "freed" to provide a better quality of life for workers. In 1989, he was missing the connection with the new orientations of sociology of tourism dominated by Anglo-Saxon researchers (MacCannell, Cohen, Graburn, etc.). They were concentrated around the journal Annals of Tourism Research and within the Sociology of Tourism working group (not a structured section) of the IAS (International Association of Sociology), as well as around the nascent Mediterranean Association of Sociology of Tourism managed by Asterio Savelli. Moreover, in previous years, M had studied free time in advanced-economy cities in relation to working times, according to a French model that considered these residual activities with respect to work issues, the alpha and omega of industrial citizenship.

As a result, in 1989 he read my book and that of Asterio Savelli published at the same time, both entitled "Sociology of Tourism", which sought to summarize the national and international debate on the sociology of tourism (Costa, 1989; Savelli, 1989). While appreciating and supporting our work, M politely declared that he was dissatisfied with the results produced by the new discipline at the beginning of the 1990s. According to M, research by the "territorialists", i.e. sociologists who studied tourism processes formed in organized space (e.g. the many contributions on the economic, environmental and socio-cultural impacts of tourism), also underestimated 
the fact that tourists were a segment of a larger population: a population $\mathrm{M}$ called city users. It was a population so important as to shape the new social morphology of advanced-economy cities. A population not to be restricted to the free time and shopping of residents and tourists; it also applied to students, the elderly, sportsmen. City users were the result of a new protagonism of advanced-economy cities, competing with each other to attract metropolitan business persons, talented immigrants, researchers and students, financial investments, sportsmen, people in entertainment, goods.

$\mathrm{M}$ asked Italian and foreign sociologists of tourism to take a step forward: to update the approach and include their contributions within a macro-sociology of the cosmopolitan city on the move, the "second-generation metropolis" and the nascent "third-generation metropolis" characterized by mobility induced by metropolitan business persons. This was an idea he would reaffirm to an international audience in 1999 in his book "A City for Whom? Transients and Public Life in the Second-Generation Metropolis" (Martinotti, 1999). He asked researchers to investigate motivations and behaviours of tourists within the city users, identified as a "new class, relatively free of location" (Martinotti, 1999: p. 168).

Empirical analyses of how city users model urban spaces was the starting point for a later attempt to provide a broader generalization on the economic-social dynamics of contemporary capitalism and to consider the hospitality/mobility binomial a production system of the new metropolis. This suggestion was difficult to follow. It was difficult to establish a link with studies based on the international literature dealing with the sociology of tourism, which at that time was much more interested in cultural issues. The working group of sociologists of tourism (for example, the conference in Nice in 1992 entitled "Tourism between Tradition and Modernity", in which Asterio Savelli and I participated) was very attached to the sociology of culture (Actes du colloque international, 1993). It is enough to think of the authenticity of the tourism experience presented by Dean MacCannell or the phenomenology of the tourist experience of Erik Cohen or the anthropological view of the culture shock of intercultural communication proposed by Nelson Graburn or the centre-periphery idea of Marie Lanfant or the idea of tourism mythologies of Tom Selwyn. Thus, when in 2005 I wrote the introduction to the Italian translation of a classic of sociology of tourism ("The Tourist. A New Theory of the Leisure Class" by Dean MacCannell) (Costa, 2005), I mentioned that the roots of the book were in Simmel, in Durkheim, in Goffman, but not in urban sociology in the narrow sense. In fact, I recalled M's observations many years earlier. Indeed, the work of grafting sociology of tourism on urban sociology was in an early phase at the end of the 1980s.

The English- and French-language geographers of tourism had already developed models of tourism space in the 1970s (Miossec, 1977; Butler, 1980). They had discussed the concepts of tourism region and urban tourism, linking them to local production systems, going beyond the idea that the tourism act was exclusively a variant of tourist consumption during leisure time. They were close to the issues raised by M. Nevertheless, the interdisciplinary approach was also slow in this sector of tourism studies. In Italy, we had to wait until 2009 before a geographer, Montanari (2009), wrote a book which, integrating the national and international literature in an interdisciplinary manner, was dedicated to "urban tourism"; it was part of a Bruno Mondadori/Pearson series directed by M, Montanari and myself. Therefore, the interdisciplinary connection between the city users theory and the geography of tourism was easier in the early 1990s but still complex. It required (and requires) further theoretical elaboration, the ability to work in a team, crossed citations overcoming corporate barriers and hierarchical affinities deeply rooted in Italy.

Precisely in those years, there arose in $M$ the need to create a team of experts. A few years later, he supported my idea to start a journal that would link the national debate on tourism to the international one and to the interdisciplinary approach, favouring issues related to space and mobilities. With the help of the Lombardy Region, we founded a journal Annali Italiani del Turismo Internazionale, which lasted only two years (1996 and 1997) and included a total of eight issues, unfortunately with limited distribution. It was based in the Department of Sociology, University of Milan, and had an interdisciplinary nature. The scientific committee consisted of the psychologist Marcello Cesa Bianchi, the geographer Giacomo Corna Pellegrini, the anthropologist Nelson Graburn, the French economist-sociologist Marie Francoise Lanfant, the Italian sociologists Vincenzo Cesareo, Antonio de Lillo, as well as the sociologists Erik Cohen, Dean MacCannell, Krzysztof Przeclawski and John Urry.

$\mathrm{M}$ wrote an article for the first volume, composed mainly of articles translated into English so as to deprovincialize the Italian academy which was little inclined to interdisciplinary innovations in tourism. M's article was entitled "City Users a Milano" (Martinotti, 1995: p. 181-197): the final section reprised the third chapter of "Metropoli" (1993), defining the Lombard capital city as a second-generation metropolis. Unlike many scholars of the time who associated the decline of the Fordist industrial city with the general decline of cities, M analysed 
the factors of the resurgence of Milan. In parallel, he argued that Milan would have been included in the new trend if the City Council had planned mobilities and thus the constructed city, talking about specific patterns of European mobility "very different from those of the other geopolitical blocs, Eastern Europe, the USA and Japan" (p. 193). M maintained that the absence of a Monitor of city users explained why Milan was "indecipherable" in the new spatial and demographic configurations. In an explicit manner (and we are in 1995), he concluded that "it is therefore necessary to describe the mobility of business people, cultural and recreational tourists, students, the elderly and all transient people who use the services offered by this active city. With this new information, public administrators will be able to intervene to improve hospitality with greater managerial efficacy. In this sense, tourist mobility is an important indicator of the more general transformations under way in second-generation metropolises. And we will devote particular attention to tourist mobility in future issues of Annali Italiani del Turismo Internazionale" (Martinotti, 1995: p. 195). Unfortunately his hope was in vain, also because the municipal, Lombard and Italian governments did not set up a Monitor of city users. Although political attention to the issue has increased, the decision-making processes are still not based on the new statistics of urban mobility advocated by $\mathrm{M}$.

M was not the only one in those years to desire a new intersectorial and interdisciplinary approach to the study of tourism, included in the broader context of advanced-economy cities, of the city of information flows, of intense exchanges and accelerated mobilities. Yet we must not look at the debate on globalization and global cities, which strangely ignores tourist flows and studies on tourist mobilities - a well-known limit in the American urban sociology circles that $\mathrm{M}$ frequented regularly. Thus, $\mathrm{M}$ was not surprised when I showed him the 2006 article by Dennis Judd on "Tourism Geographies" (Judd, 2006), which diagnosed the limit of Saskia Sassen's thinking on global cities (Sassen, 1991), due to the lack of analyses of tourist flows as typical aspects of global cities and as a production system of the post-industrial city. "Let's try to remind her of it", M replied with his usual elegant sarcasm.

It was necessary to turn to the sociology of tourism developed in Britain based on the influential thinking of Anthony Giddens to contextualize M's innovative city users theory. The book by John Urry (U), "The Tourist Gaze", was released in 1990 (Urry, 1995 or 1990). In the subtitle and in various passages, it considered tourism as a variant of a more comprehensive theory of "travel" in contemporary society. The effect of U. book in Italy was mainly the initiation of many reflections on cultural or visual sociology, focused on the "social construction" of the tourist gaze. Above all, it stimulated aesthetic ideas or those focused on cultural diversities in shaping urban landscapes ("collective gaze", "romantic gaze", "ordinary/extraordinary dynamics", etc.). It was necessary to wait until 2003 when Rossana Bonadei and Ugo Volli invited both M and U to a conference on Lake Garda. The conference organizers published the proceedings under the title "The Tourist Gaze and the Narrative of Places" (Bonadei \& Volli, 2003). The very fact that the "narrative of places" was favoured demonstrates that the orientation of the conference was once again more cultural, focusing on the languages and narratives that construct the tourism space, related to socio-demographic analyses and travel mobilities. Moreover, the organizers were humanists (literary scholars and semiologists). Also the Urry's intervention was focused during the Lake Garda conference on the connection between consumption and tourist gaze and not on the growing role of the mobile lives (Urry, 2003). M met U on that occasion and highly appreciated both U's attempt to articulate the "new paradigm of mobilities" as a focus of sociological thinking, making tourism implode within the new approach, and his intention to launch a journal dedicated to "Mobilities". U's approach was a clear extension of the theory of city users and new metropolitan populations, even if U knew it only indirectly. U read M's 1999 paper in English only after M's death, and thus the confrontation between the two approaches did not develop after the 2003 meeting.

However, the novel paradigm of new mobilities (Sheller \& Urry, 2004; Urry, 2007; Elliot \& Urry, 2010) was developed by $U$ and by English sociologists. Along with the idea of the new creative class by Florida (2002; 2005 ) and that of the new international middle class of professionals who live between cities and generate the serious tourism studied by Stebbins (2007), it became another main topic of contemporary thinking on tourism and "beyond" tourism. Cities continue to engage in urban planning, in the planning and management of services to improve the quality of life of residents, workers and visitors, be they immigrants or tourists or metropolitan-business persons, while the local and inter-city means of transport are increasingly at the centre of public attention. City users are not organized and visible like the old working class represented by trade unions. We realize their importance "negatively" when taxi drivers or air traffic controllers or municipal employees decide to go on strike. Transport workers are the only categories that affect the whole community. They are the only ones 
that attract the attention of city users, of the new professional middle class that uses means of transport so intensely. Indeed, transport plays an essential role in their economic, political and cultural hegemony, exactly because freedom to move between cities gives them their competitive advantage.

\subsection{Local Community and Hospitable City between Urban Marketing and Bottom-Up Regulation}

A new direction in urban planning emerged between 1985, when Murphy's book on the community approach to local tourism development came out (Murphy, 1985), and 1993 when Ashworth and Voogd's "Selling the City" was published (Ashworth \& Voogd, 1993). The book "Metropoli" became part of the debate on the urban regeneration of deindustrialized cities, the rise of the economic service sector as an engine of local development and the competitive growth of metropolitan areas as national borders were becoming increasingly permeable to exchanges of people and goods.

For a long time (and sometimes even today), cities were considered fragile organisms with respect to the big players of international tourism. Studies on the impacts of mass tourism correctly showed the negative aspects caused by localization imposed from above by the big players according to a vertical or colonial integration of the destination. Examples are Doxey's Irridex (Doxey, 1976) and Butler's tourist area life cycle (Butler, 1980), in which residents refused tourists when they went from "many" to "too many". The tourist cities or resort towns identified by Max Weber were only the passive containers of mass tourism expressed by what $\mathrm{M}$ called first-generation or industrial metropolises.

$\mathrm{M}$ argued that, as second-generation metropolises, cities could play an active role, planning their development in a conscious and responsible manner. Sustainable tourism (a term coined in 1992 during the Rio Conference based on the limits of boundless development and of mass tourism, and urban marketing, i.e. the ability of local elites to selectively attract and manage capital and visitors) was not excluded. Cities regenerate themselves, they transform abandoned industrial areas into new financial areas and host creativity industries, they build universities on the periphery and count on the centrality of services to make such places hospitable for residents and visitors who choose them, even for a short period of their life or intermittently, because they are "elective centres" in which the places adapt to them and not they to the places. With his 1993 book, M fit into the new orientations that detected the active role of cities in attracting and wisely managing tourists, especially tourists segmented by their "sustainable" lifestyle and distributed throughout the year to decongest the areas and to create stable jobs, overcoming the seasonality of Fordist mass tourism.

Knowledge of urban marketing came to $\mathrm{M}$ from the scientific literature but also from direct participation in EU projects such as "Eurocities" or, as a consultant to Milan's mayors, in the drafting of preparatory documents to try to attract European centres to Milan, such as the European Environmental Agency in 1990-1991 (I was secretary of the Promotional Committee, $\mathrm{M}$ was on the Scientific Committee) or from direct participation in conferences organized by new pressure groups such as AIM (Association of Metropolitan Interests) to which M. explicitly referred in his 1993 book. In the early 1990s, M thought that the active role of urban regeneration should be guided by the local political elite open to international investors who must be regulated from the bottom up, on an urban scale. M argued in "Metropoli" that it was necessary to find a balance between urban marketing and local culture, between corporate infatuations in "selling" the city and new techniques for organizing what in 2004 he would call the "urbs hospitalis". This was an idea I would reprise in 2008 in book "La città ospitale" ("The hospitable city"), i.e. the city guided by culture and by values as well as by economic interests (Costa, 2008).

M's position on the desirability of "regulating" urban marketing (and not rejecting it with intellectual snobbery) was established in 1993. When I participated in the Gorbachev Foundation's international conference "Economia del Sole" in Rimini in that year, M suggested addressing the topic of how seaside tourist cities were shaped by the new populations of transient people and the related commercial intermediaries. The city users theory worked very well in that circumstance: I argued that the seaside tourist was a multi-motivated subject and that single-function cities were lagging behind in development because they organized services for declining seaside mass tourism coming from first-generation metropolises, thus acting as "pleasure suburbs". Only seaside cities that diversified the offer would become multi-functional to satisfy both multiple market niches and the individual seaside tourist, who was no longer content just to relax, work on a tan and "do sweet nothing" but wanted to play a relational role, interacting with the local population (Costa, 1993). Therefore, M and I proposed 
a new way to program hospitality: while the summer holiday was typical of first-generation metropolises, the new seaside cities had to be modelled to attract visitors throughout the year, to desynchronize the times of consumption and to plan a new production system based on hospitality and mobility.

The theory of "regulation" was the basis of urban tourism planning. The topic was addressed by M and I in the article "Sociological theories of tourism and regulation theory" in the 2003 book "Cities and Visitors" (Costa \& Martinotti, 2003: p. 53-71). Lily Hoffman, Susan Feinstein and Dennis Judd asked M to apply the city users theory to Venice. Coincidence would have it that the mayor of Venice was a regional tourism economist, Paolo Costa, who had involved us in seminars and lectures. As mayor he had applied the macro-technique of "carrying capacity" with the tax on tour operators and tour buses the year before, in 2002. Paolo Costa shared M's view of having to manage flows without the snobbish idea of demarketing ("chasing tourists away") and of agreeing with the stakeholders on bottom-up, community driven rules. Thus, $\mathrm{M}$ and I reported on the case study of Venice to underline those historical-artistic cities, those tending toward hypertourism, i.e. toward a "third"-generation metropolis in which visitors outnumber residents in many months of the year, can be regulated with specific urban policies. Tourists are not worse or better than residents; the quality of life depends on how the community approach and spatial mobilities are planned and managed. M and I wrote in 2003: "the case of Venice demonstrates that the macro and micro management techniques regarding the environmental impacts of tourism are efficient if they start from the bottom, if the stakeholders mediate the diverging points of view and apply principles of participation, information and negotiation (Costa \& Martinotti, 2003: p. 68). And then: "the simultaneous use as applied to competitive and collaborative strategies in tourism planning and destination management by organizational stakeholders merits greater examination in the field of regulation theory of tourism" (Costa \& Martinotti, 2003: p. 68). In M's summary the following year: "Tourism and technologies, the local communication networks of the urbs hospitalis also allow one to reunite the visitors with the local populations" (Martinotti, 2004: p. 83).

The idea of the active role of cities in programming themselves as globally hospitable led $\mathrm{M}$ to reprise a classic theme of urban sociology: the sense of place. Martinotti (1999: p. 170-172; 2003: p. 11-12; 2004: p. 75-84) maintained that devaluation of the meaning of places built by the tourism economy and by shopping (recreational parks, hubs, railway stations, shopping malls, multimedia services in cultural heritage, virtual museums) was an analytical error. In particular, the "non-place" theory of the French anthropologist Augé (1995 or 1992) seemed off the mark to him. M wrote "shopping malls are not non-places, they are places as we desire them, and they are places of modernity. They are places as we like them" (Martinotti, 2004: p. 80) and then "the communities formed in shopping malls and in mainly tourist cities are formed by rational consumers. It is necessary to read the "signs" of the new territorialization of tourism (Martinotti, 2004: p. 83). In short, even places of radical modernity experience conflicts, ways of life are delineated, collaborative partnerships are formed, the visual culture of architects gives aesthetic value to spaces, and city users live there with their specific ways of giving rational sense to social action (Martinotti, 2003).

\section{University Tourism Education According to M: Reconciling Theory and Practicality}

\subsection{Origins}

$\mathrm{M}$ was a great educator. Sometimes he devoted more time to his students than to his collaborators. He was a man who spoke with everyone because he was curious and attentive to diversity of opinions. He had the attitude of the progressive intellectual committed to providing students with equal opportunities through education and thus promoting their social mobility through the merit achieved with higher learning.

To reconcile political values and educational planning, M proposed the "Martinotti bill" to Minister Berlinguer in 1997, which was the basis of the subsequent university reform establishing three-year degrees and specialist degrees (later called "magistrali" in Italy), the so-called $3+2$ system. I collaborated with him in defining the main motivations to establish the three-year degree course in Tourism Sciences and the two-year course in Planning and Management of Tourism Systems. M gave a summary of the discussion in an article in the third issue of Sociologia Urbana e Rurale in 2001 and in another article, of which I was co-author, "Il turismo nella autonomia didattica degli atenei (riforma universitaria)" (p. 513-526) for the Tenth Report on Italian Tourism commissioned by the Ministry of Industry and Economic Development (Costa \& Martinotti, 2001).

In truth, the motivation, or rather the meta-motivation, was political. It was related to the democratization of 
university access, to the fact that $\mathrm{M}$ wanted a higher number of Italian university graduates in general and tourism graduates in particular. In fact, high school graduates were enrolling (and still enrol) in hospitality training institutes and technical institutes for tourism because families often could not (and cannot) afford to pay for their university studies. Thanks to the historicist-spiritualist educational vision in Italy that went back to Croce and Gentile, young tourism students in the 1980s-1990s were destined to play a service role with low-level, mainly executive skills lacking High Culture. $\mathrm{M}$ argued instead that the new economy of knowledge impacted on the re-skilling of the operators. Therefore, in Italy we should train multi-purpose workers with middle skills and cultural knowledge. He refused the ghettoizing vision of tourism jobs. Language skills, abilities to use information technology (web marketing), knowing how to organize the offer (network model), having a cosmopolitan humanist culture to dialogue with everyone without prejudice (also Lewin, 2009; Byrne-Swain, 2009), knowing how to exploit the enormous Italian cultural heritage, the ability to plan recreational or artistic events required (and requires) activities of "empowerment" of tourism workers. Therefore, M devised and constructed a new university reform with a novel educational mix of territorial, social, economic, business, literary and technological disciplines. This would be beneficial to young people in that, through tourism studies, they could participate in global teams and manage the dynamics of international tourism, promoting in particular the Italian cultural heritage in international tourism markets. In summary, the three-year degree was to be an opportunity to improve the active citizenship of tourism workers and to prepare young people for international work mobility. The educational model was interdisciplinary and cosmopolitan.

M was very attentive to what was emerging in the 1999-2001 triennium. In 1999 he pushed for the bill dealing with the nascent specialist degree in Planning and Management of Tourism Systems to be discussed in the Italian parliament, which in 2001 passed Law 135 establishing "local tourist systems". Therefore, the university reform hastened the system approach with the "magistrale" degree, proposing the role of planner and manager of urban tourism systems, i.e. the destination manager. The two reforms were closely related to each other.

$\mathrm{M}$ also looked outside Italy. The $3+2$ tourism degree system was modelled on the educational courses in Leeds, Guildford, Glasgow and other cities in Great Britain, all focused on international relations, interdisciplinary exchanges aimed at achieving both cognitive (knowledge) and expertise (practical skills) objectives. In more strictly didactic terms, the synthesis at the international level was made by John Tribe who in 2002 coined the term "philosophic practitioner" in an article in "Annals of Tourism Research" (Tribe, 2002): he indicated a model of tourism worker who was both a "liberal" intellectual who sought truth and beauty and an "operative" who could manage business routines effectively and efficiently. In parallel, Tribe's article on the philosophic practitioner, which we discussed with Richard Prentice in 2004 during a seminar at the University of Milan Bicocca, pushed $\mathrm{M}$ to strengthen the humanities in the three-year degree. $\mathrm{M}$ entrusted the coordination of this area to Marxiano Melotti, an interdisciplinary intellectual par excellence.

The integration of education and training was already present in the political-cultural debate that accompanied the introduction of the $3+2$ tourism degree course in Italy because $M$ was cosmopolitan and was informed about the educational processes in progress, especially in the USA and Britain.

\subsection{Consorzio Nettuno}

M's framework was tested for the first time with the Consorzio Nettuno, which managed a distance learning university diploma (not yet a three-year degree) in Economics and Management of Tourism Services in the 19981999 academic year.

Here I must make a digression. In Italy, business economists were the first to consider tourism a productive activity and not an activity of consumption to be associated with sport and leisure. They opened the university to tourism training with an economic and legal emphasis. M observed that this approach was a good step forward and it was appropriate to take another one that would connect companies and the territory in a systemic community vision of local tourism development. The sociologists of the Mediterranean Association of Sociology of Tourism and the journal Annali Italiani del Turismo Internazionale (despite its short life) had given many contributions in this regard: they dealt with the role of the local population, introduced ideas on social networks that facilitate or hinder territorial cohesion, and analysed the models of governance and local-global connections in the promotion-commercialization of innovations realized in a bottom-up participatory manner, as well as the macro- and micro-techniques of managing tourism impacts on the local community.

M transferred the systemic and community approach into the Sociology of Tourism module produced in 1998 
for the Consorzio Nettuno when he was teaching at the University of Milan and no longer at Milan Bicocca. There were VHS recordings broadcast by RAI2 late at night, and thus the lectures were seen both by students enrolled in the university diploma course (who wrote the exams in the various consortium branches) and by the general public. Therefore, $\mathrm{M}$ also received phone calls from sleepless restaurateurs, hotel porters working the night shift and tourism workers in general who simply felt the need to improve their knowledge. And this "democratic" success gave $\mathrm{M}$ much pleasure.

The initial module was highly appreciated by the managers of the Consorzio and $\mathrm{M}$ was asked to record another in 2000, which he called Planning the Development and Structure of the Territory. It was an opportunity to start thinking about the sociologist of tourism as a professional with distinctive expertise in how to collaborate with urban planners to support the decisions of local administrators in attracting investors and visitors and in integrating immigrants through tourism services (hotels and restaurants, in particular).

In both modules, $\mathrm{M}$ wanted to test a teaching model that would reconcile sociological theory and sociology applied to visible phenomena in organized space. In the introductory lectures, $\mathrm{M}$ formulated macro-sociological scenarios to explain modern society and contemporary urbanism. He wished to introduce into the students' minds the habit of thinking based on qualitative and quantitative variables with which to analyse a problem posed in the middle of the lecture: he wanted to form open minds, lacking rigidity and willing to explain social facts by means of other social facts and not according to the will of individuals or merely subjective points of view. And he did it with simplicity. Therefore, when he explained the processes of disembedding and re-embedding taken from Giddens' book "The Consequences of Modernity" (Giddens, 1994 or 1990), he also discussed examples related to tourism, such as conference tourism: teleconferences and information technologies indicate a process of disembedding (of territorial breakdown because they connect people at a distance) but also help to reconfigure face-to-face meetings and generate new ways of organizing conferences (re-embedding). In this way he demonstrated that the apocalyptic idea of the disappearance of conferences, advanced by some scholars in the 1990s, was an unjustified fear. He induced "positive thinking" in those who listened to him, the idea that it was possible to use information technologies to take reasoned decisions and create a better tourism society. The initial scenarios were followed by lectures on sociology of tourism in the strict sense, which referred, when possible, to some ideas previously presented by M. Then there were lectures by various collaborators, also from different disciplines. Thus, for example, Walter Santagata, a cultural economist, gave some lectures on his ideas, relating them to tourism and the growing role of "cultural districts" (Santagata, 2014).

The second module, on Planning the Development and Structure of the Territory, was compact. It provided the tools for a new public management that would be more efficient in coordinating urban planning. It outlined the up skills of the destination manager (dealt with exhaustively in the international scientific literature) and also presented many case-studies on desirable partnerships in public projects and private initiatives.

\subsection{The Three-Year Degree Course in Tourism and Local Community Sciences}

The teaching experience of the Consorzio Nettuno (Costa \& Martinotti, 1999-2005) was transferred to the threeyear degree course in Tourism and Local Community Sciences begun at Milan Bicocca in the 2001-2002 academic year, of which $\mathrm{M}$ was the first coordinator. $\mathrm{M}$ wished to include "local community" directly in the name of the degree course to clearly indicate the centrality of "responsible" hospitality and he sometimes asked me "but why don't we call the destination manager the hospitality manager?". The concept of hospitality resulted from the debate on "sustainable" tourism which placed the local population at the centre, from the thinking of the Mediterranean Association of Sociology of Tourism which in 1999 had attributed a central role to the community approach (Guidicini \& Savelli, 1999; Savelli, 2004), and from M's idea that the places of radical modernity or of hypertourism also satisfied rational needs that had to be understood, criticized and improved with projects utilizing the post-modern mix for reasoned "bottom-up" growth.

M taught the General Sociology course (3 credits) in the first semester of the first year, while I taught the Sociology of Tourism course ( 3 credits) in the first semester and again in the second semester ( 6 credits). In the second year, the sociological approach continued with Sociology of Work. The same logic held for Business Economics or for Law: first the general aspects and then the advanced ones. As can be seen from the course programs, such as that of 2004-2005, M's module addressed the "problems" of sociology and built interdisciplinary bridges so that the students would understand that it was an interdisciplinary educational project. In parallel, he used Boudon's textbook to teach the methods of social research (Boudon, 2001 or 1970). 
$M$ reinforced the internship office with qualified people and encouraged direct interventions in the classroom by entrepreneurs and non-profit associations. He wanted to bring out the "tacit" knowledge of those operating successfully in global markets, especially in Italian incoming.

Internship experiences solidified M's conviction of calibrating liberal education and professional skills training through exercises and workshops based inductively on the study of several cases. Thus, he entrusted some business management and organization modules (as well as entertainment management) to "reflective" professionals who reconciled direct experience with the desire for study and teaching, expanding the number of "contract lecturers" who often met with great success among the students. In this way, M and I tried to correct one of the paradoxical effects of critical theory: the legitimacy of deskilling in tourism works. Indeed, many students, after listening to a lecture on "simulacra", "panopticon", "heterodirection", "Disneyfication", "McDonaldization", "liquid society", were somewhat lost because they thought that strong powers were manipulating them, creating precarious jobs, turnover, seasonality, an informal economy, repression of rights, and even moral vices such as Veblen's “conspicuous leisure” (Veblen, 1999 or 1899).

The lectures by professionals and executives introduced pluralistic values into the course and allowed the more "practical" students to find their way and obtain the degree, even though many had struggled to deal with the complex issues of critical social philosophy which then was only a component of the educational project. Popper's open society and pluralism (Popper, 1966) distinguished the degree course, in which space was also given to the organization of religious tourism management taught by an enlightened Catholic priest, because a large part of the Italian cultural heritage is managed by Catholic authorities. No one best way, then, but many mixtures of knowledge and practices in a full post-modern paradigm "open" to free "interpretations" (for postmodern planning as a legacy of the Enlighement, see Allmendinger, 2001)

\subsection{Teaching of Sociology, City Marketing and City Users}

There is a question that still generates controversy among sociologists: whether or not it is appropriate to teach urban and territorial marketing in a course of applied sociology. With $\mathrm{M}$, the question was never raised in terms of epistemological legitimacy but rather of methodological skills.

From 1993, M had me lead a seminar "City Marketing and City Users" in the Urban Sociology course for the Political Science degree in the University of Milan. In 2004, M called the three credits of sociology of tourism Analysis and Planning of Territorial Networks for Tourism, both for the Consorzio Nettuno and for the threeyear degree course at Milan Bicocca. That the sociologist could be a professional able to develop analyses and projects to meet the needs of local authorities and businesses was more than acceptable for $\mathrm{M}$, it was meritorious. But it was necessary to possess the relevant tools. Therefore, along with me, in 2002 he wrote the Introduction (Costa \& Martinotti, 2002) to the Italian translation of "The Tourism Development Handbook" by Godfrey \& Clarke (2002), highlighting the fact that many socio-territorial aspects would redefine territorial marketing in a more sociological and geographical perspective. We used this textbook in our teaching, along with Luigi Guiotto who had translated it, to the full satisfaction of students oriented toward tourism professions.

The following are the aims of the "Analysis and Planning of Territorial Networks for Tourism" module still present in the Nettuno database and in the course program of Tourism and Local Community Sciences: "the course will analyse the territorial networks of incoming tourism with an inductive socio-territorial approach. The lessons simulate a professional commission received from one or more local administrations to realize a tourism development plan aimed at the planning of territorial networks that integrate and valorize local resources. The aims of the module are professionalizing. Hence, students will be taught "how to" analyse the pro-tourism social capital and evaluate the expansive glocalism of local communities and "how to" foster collaboration among stakeholders in improving the local offer. They will be instructed "how to" draw up a territorial marketing plan for tourism and manage and promote a destination. Therefore, the educational goal is to transform knowledge into skills that characterize the local tourism development professional. At the end of the course, the student will be able to analyse local communities by defining indexes and types of levels of integration and be able to draw up, albeit in general terms, a territorial marketing plan and a plan for the improvement of a particular type of tourism offer.

Of course, in all this, the satisfaction of city users and the new mobilities studied by $U$ was at the centre of the urban planning. The sociologist is a facilitator of the local sustainable development with distinctive up skills (Costa, 2013). 


\section{Limitations of the Study and Implications for the Mobility/Hospitality Binomial}

M's ideas on tourism and tourism education constitute a legacy of thought and action that has yet to be understood in all its scientific implications. This study is only a position paper to frame the key issues and to underline certain passages in the period 1989-2009 when M played an influential role.

To continue M's thinking, it should be reiterated that tourism is not an independent phenomenon but is interconnected with other sectors of the economy, and that interdisciplinary convergence is the most effective method to comprehend its intersectorial dependences.

Based on the concepts of hospitable city and city users, the hospitality/mobility binomial constitutes the production system of second- and third-generation metropolises. Sociologists, geographers, urban planners and economists of the city - yesterday as today - can converge in the direction of the hospitality/mobility binomial to develop studies for the resolution of problems posed by local administrators, workers, companies and associations, and to provide solutions to enhance the quality of life of city users by means of collaborative partnerships.

In this context, a Monitor which is local and global, and interuniversity and interdisciplinary, in agreement with the municipalities and the city users, as proposed by M in the 1990s, may be the best way to capitalize on his intellectual legacy.

\section{References}

Actes du Colloque International (1993). Uresti-Cnrs-Institut de Prospective du Tourisme. Le tourisme international entre tradition et modernite, Nice, 19-21 November 1993.

Allmendinger, P. (2001). Planning in Postmodern Times. London-New York: Routledge.

Ashworth, G. J., \& Voogd, H. (1993). Selling the City. Marketing Approaches in Public Sector Urban Planning. London: Wiley.

Augé, M. (1995 or 1992). Non-Places. Introduction to an Anthropology of Surmodernity. London-New York: Verso.

Bonadei, R., \& Volli, U. (Eds.) (2003). Lo sguardo del turista e il racconto dei luoghi. Milano: Franco Angeli.

Boudon, R. (2001 or 1970). Metodologia della ricerca sociologica. Bologna: Il Mulino.

Butler, R. W. (1980). The Concept of a Tourism Area Cycle of Evolution: Implications for Management of Resources. Canadian Geographer, 24, 5-12.

Byrne-Swain, M. (2009). The Cosmopolitan Hope and Tourism. Critical Action and Word Making Vistas. Tourist Studies, 11, 505-515.

Costa, N. (1989). Sociologia del turismo. Milano: Iulm.

Costa, N. (1993). Il luogo immaginato, in Fondazione Gorbaciov and Fondazione Pio Manzù, L'economia del sole, Rimini, Fondazione Manzù, Vol. 2, pp. 235-241.

Costa, N. (2005). Introduzione a. MacCannell, D. (2005 or 1976). Il Turista. Una Nuova Teoria della Classe Agiata (pp. 15-35). Torino: Utet.

Costa, N. (2008). La città Ospitale. Milano: Mondadori-Pearson.

Costa, N. (2013). The Applied Sociology of Tourism. The Up Skills of the Facilitator in the Italian Hospitality Industry. Advances in Applied Sociology, 3, 1-12.

Costa, N., \& Martinotti, G. (2001). Il Turismo nella Autonomia Didattica degli Atenei (Riforma Universitaria). In E. Becheri (Ed.), Decimo Rapporto sul Turismo in Italia (pp. 613-626). Firenze: Mercury.

Costa, N., \& Martinotti, G. (2002). Un Manuale per Studenti e Operatori dei Sistemi Turistici Locali. In K. Godefrey, \& J. Clarke (Eds.), Manuale di Marketing Territoriale per il Turismo (pp. 15-26). Firenze: Le Monnier.

Costa, N., \& Martinotti, G. (2003). Sociological Theories of Tourism and Regulation Theory. In L. M. Hoffman, S. S. Fainstein, \& D. R. Judd (Eds.), Cities and Visitors (pp. 53-73). London: Blackwell. http://dx.doi.org/10.1002/9780470773673.ch3

Costa, N., \& Matinotti, G. (1999-2005). Lessons of "Sociology of Tourism" and "Territorial Planning”. In Consorzio Nettuno. www.uninettuno.it

Elliot, A., \& Urry, J. (2010). Mobile Lives. London-New York: Routledge.

Florida, R. (2002). The Rise of the Creative Class. New York: Basic Books.

Florida, R. (2005). Cities and the Creative Class. London-New York: Routledge.

Giddens, A. (1994 or 1990). Le Conseguenze della Modernità. Bologna: Il Mulino. 
Godfrey, K., \& Clarke, J. (2002). Manuale di Marketing Territoriale per il Turismo. Firenze: Le Monnier.

Guidicini, P., \& Savelli, A. (Eds.) (1999). Strategie di Comunità nel Turismo Contemporaneo. Milano: Franco Angeli.

Judd, D. (2006). Commentary: Tracing the Commodity Chain of Global Tourism. Tourism Geographies, 8, 323-336. http://dx.doi.org/10.1080/14616680600921932

Lewin, R. (Ed.) (2009). The Handbook of Practice and Research in Study Abroad. The Quest for Glabal Citizienship. New York-London: Routledge.

Martinotti, G. (1993). Metropoli. Bologna: Il Mulino.

Martinotti, G. (1995). City Users a Milano. Annali Italiani del Turismo Internazionale, 1, 181-197.

Martinotti, G. (1999). A City for Whom? Transients and Public Space in the Second-Generation Metropolis. In R. A. Beaurgard, \& S. Body-Gendrot (Eds.), The Urban Moment. Cosmopolitan Assays in the Late-20th Century City (pp. 155-183). London: Sage.

Martinotti, G. (2003). I Luoghi (Veri) della Modernità Radicale. In R. Bonadei, \& U. Volli (Eds.), Lo Sguardo del Turista e i Racconti dei Luoghi (pp. 91-119). Milano: Franco Angeli.

Martinotti, G. (2004). Urbs Hospitalis. Visitors in the City. In A. Savelli (Ed.), Città, Turismo e Comunicazione Globale (pp. 75-84). Milano: Franco Angeli.

Miossec, J. M. (1977). Un model de l'espace touristique. Espace géographique, 6, 41-48. http://dx.doi.org/10.3406/spgeo.1977.1690

Montanari, A. (2009). Turismo Urbano. Milano: Mondadori.

Murphy, P. E. (1985). Tourism. A Community Approach. New York-London: Methuen.

Popper, K. (1966). The Open Society and Its Enemies (5th ed.). London: Routled and Kegan Paul Ltd.

Santagata, W. (2014). Il governo della cultura. Bologna: Il Mulino.

Sassen, S. (1991). The Global City. Princeton, NJ: Princeton University Press.

Savelli, A. (1989). Sociologia del Turismo. Milano: Franco Angeli.

Savelli, A. (Ed.) (2004). Città, Turismo e Comunicazione Globale. Milano: Franco Angeli.

Sheller, M., \& Urry, J. (2004). Tourism Mobilities. London-New York: Rouledge.

Stebbins, R. A. (2007). Serious Leisure. New Brunswick: Transactions Publishers.

Tribe, J. (2002). The Philosophic Practitioner. Annals of Tourism Research, 29, 338-357.

http://dx.doi.org/10.1016/S0160-7383(01)00038-X

Urry, J. (1995 or 1990). Lo sguardo del turista. Roma: Seam.

Urry, J. (2003). I turisti Consumano i Luoghi? In R. Bonadei, \& U. Volli (Eds.), Lo sguardo del turista e il racconto dei luoghi (pp. 147-155). Milano: Franco Angeli.

Urry, J. (2007). Mobilities. Cambridge: Polity Press.

Veblen, T. (1999 or 1899). La Teoria della Classe Agiata. Torino: Einaudi. 
Scientific Research Publishing (SCIRP) is one of the largest Open Access journal publishers. It is currently publishing more than 200 open access, online, peer-reviewed journals covering a wide range of academic disciplines. SCIRP serves the worldwide academic communities and contributes to the progress and application of science with its publication.

Other selected journals from SCIRP are listed as below. Submit your manuscript to us via either submit@scirp.org or Online Submission Portal.
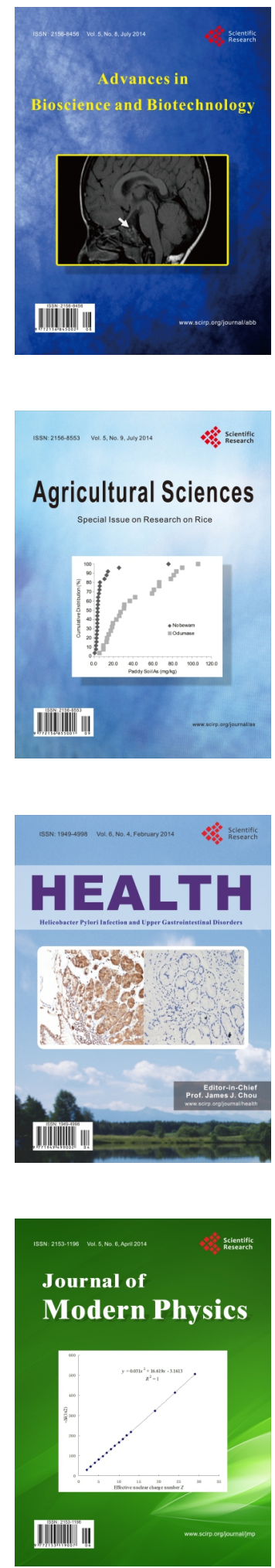
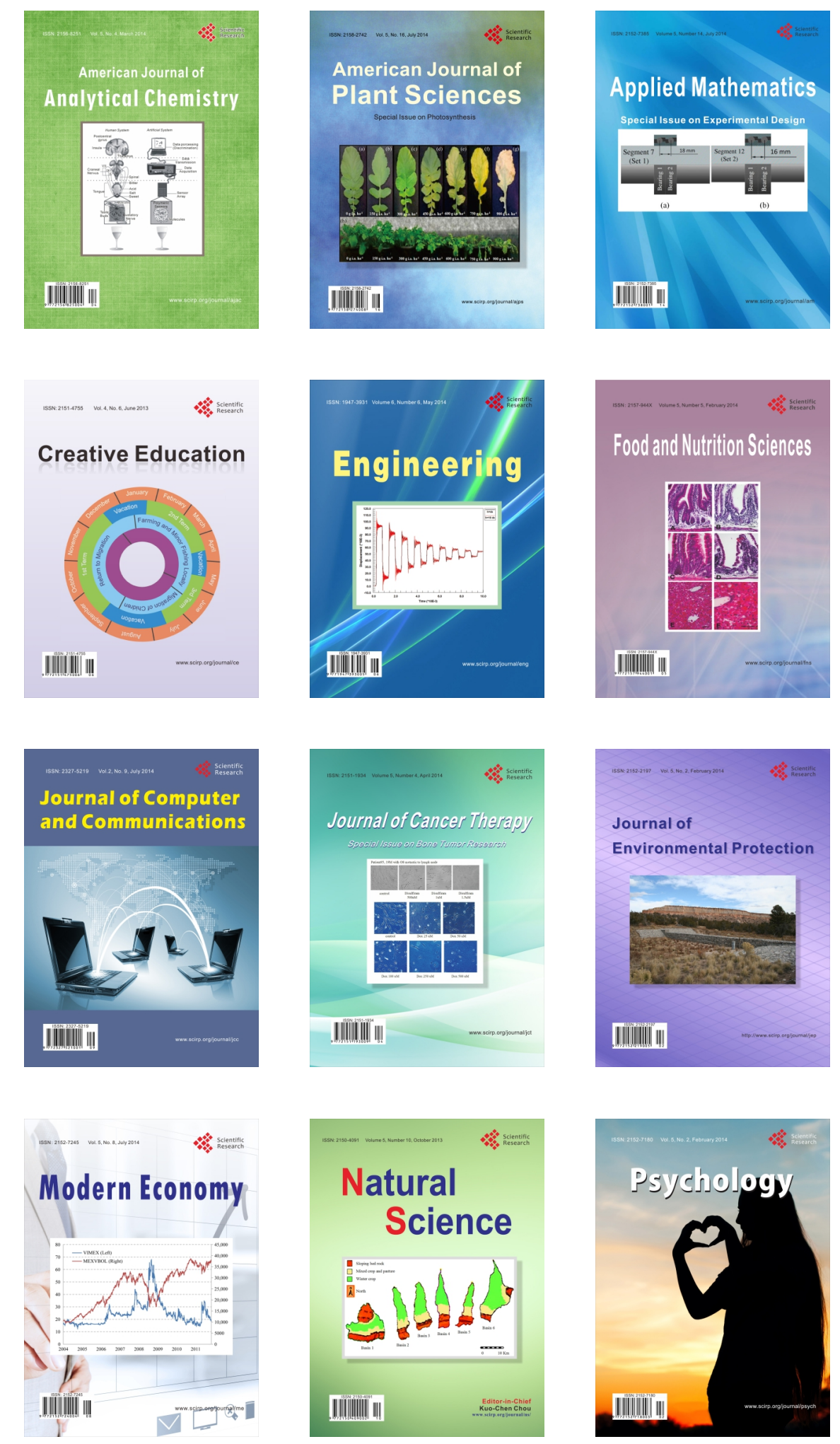